\title{
An application of BIM technologies in typical dwelling building projects
}

\author{
Darius Migilinskas ${ }^{1}$, Juozas Katkus ${ }^{2}$, Mykolas Sadauskas ${ }^{3}$ \\ ${ }^{I}$ Department of Construction Management and Real Estate, Faculty of Civil Engineering, \\ Vilnius Gediminas Technical University, Vilnius, Lithuania \\ ${ }^{2,}{ }^{3}$ Department of Reinforced Concrete Structures and Geotechnics, Faculty of Civil Engineering, \\ Vilnius Gediminas Technical University, Vilnius, Lithuania \\ E-mail: ${ }^{2}$ juozas.katkus@stud.vgtu.lt (corresponding author)
}

\begin{abstract}
The modern technologies are widely implemented in construction market including building information modeling (BIM) whitch is rapidly developing in many management segments related to design, construction, and building operation. BIM technologies are being used more and more by architects, engineers, surveyors, builders, contractors, subcontractors, construction manufacturers and building administrators who need to work together to simplify workflow and ensure that all design, construction and building operations are effective. BIM is already in use in Lithuania, but many construction market participants and mostly the customer still think that BIM is too expensive for Lithuanian construction market. The aim of this study is to analyze the benefits, opportunities, limitations, chalanges and obticles of using the BIM methodology for typical dwelling building projects. The results of resreach are based on detail payback assessment of BIM methodology use in small-scale projects and small business companies is delivered in the conclusions.
\end{abstract}

Keywords: Building Information Modeling, typical dwelling building projects, BIM uses.

\section{Introduction}

The rapid grow of the population in the World and high demand of the living area rise the challenges for participants of dwelling building projects. The implementation of the dwelling building projects must fulfill high quality requirements, fast delivery and acceptable cost level. It is complicated to make it in traditional construction way and satisfy all requirements without any loses or compromise. The use of typical and repetitive dwelling building projects become logical solution to ensure high demand with good quality level in faster and cheaper construction. The most rational solution for dwelling building projects can be based on Building Information Modelling (BIM) technologies used in construction and production industry. Building Information Modelling must be used during whole life cycle to get biggest benefits for all project participants, it means better to use Building Information Modelling during design, construction and maintenance stages. However, in the era of advanced information technologies, the implementation of dwelling building projects is the area where digital technologies are the rarely applied.

The research methods are literature analysis of BIM implementation in residential and dwelling building projects. The object of the research is real project of ten building implementation in Lithuania, real life evaluation of benefits and limitations of BIM usage, influence of time and economical aspects. In the research costs are presented with payback assessment for small-scale projects and small business analysis together delivered with results and conclusions.

\section{Literature review and investigations}

Over the past couple years, dwelling building prices in the EU have grown by an average of $5.9 \%$ compared with the dwelling building (housing) prices in 2015. This increase in this property prices is noticeable in all EU countries, but the pace of price increases in each EU country is different. In many countries, the rise in dwelling prices is stable, while in other countries, such as Sweden, Lithuania, Latvia Hungary and especially Romainia, there is a sharp rise in real estate prices, which raises concerns about overproduction in the real estate sector (Eurostat, 2018).

In Europe, housing prices are also rising due to the better economic situation. The growth of economic index in EU from 2011 to 2014 was $0.8 \%$, from 2014 up to 2016 up to $1.9 \%$ and from 2016 up to 2018 over $2.1 \%$. These economic indicators led to an increase in household incomes, and an increase in household incomes led to an increase 
the demand for housing. The stable situation of house price index during period between 2011 and 2015 changed to rapid grow over $15 \%$ in 2018 (Eurostat, 2018).

In 2015 more than 4 out of 10 people (42.0\%) lived in flats in the European Union, about a quarter $(24.1 \%)$ in semi-detached houses and one third $(33.3 \%)$ in individual detacehed houses.

The largest share of people living in flats among the European Union member states in 2017 was: Latvia (66.4\%), Spain (66.1\%), Estonia (61.8\%), Greece (60.0\%) and Lithuania (58.7\%). Most of the people living in semi-detached houses were in United Kingdom (60.4\% each), Netherlands (58.7\% each) and Ireland (51.7\%). These countries were the only Member States in which more than half of the population lived in a semi-detached house. Comparing the statistics of EU countries, the majority of people living in individual detached houses are in Croatia (70.7\%), Slovenia (65.2\%), Romania (64.7\%) and Hungary (63.8\%). In Lithuania only 5.3\% of population are living in semi-detached houses and $35.6 \%$ in individual detached houses (Eurostat, 2017).

The EU does not regulate the legal framework for housing, so the authorities of each member state develop their own housing policy. However, many EU member states face similar challenges, such as how to upgrade their housing stock, how to plan and deal with urban development, how to promote sustainable development, how to help young and disadvantaged groups to enter the housing market, or how to promote energy efficiency among dwelling house owners.

Permanent population growth in urban areas and limited development in the city have led to a reduction in the distribution of urban and rural areas. In many cities, people tend to travel from cities to suburban and suburban areas (mixed urban and rural areas) on the outskirts of urban areas. This shift was caused by: an increase in the level of motorization, the infrastructure of automobile and public transport links, the desire to improve the quality of life, the growth of cities in certain areas and the desire of people to escape poverty.

For example, during 2016-2017 period, the number of transactions related with the houses grew most rapidly in municipalities of the biggest cities in Lithuania (the number of transactions increased by 57\% compared to 2016), while in cities and districts Šiauliai and Panevėžys there was a decrease of $4 \%$ and $6 \%$ respectively. The endless construction of new apartments in the capital of the country and the revival of the market for new apartments in Kaunas offers buyers new options to choose from. Considering the favorable conditions for the acquisition and the increasing offer, the total sales of new apartments in major cities of the country are recorded past few years.

Taiking in account this grow of construction industry, companies strive to maintain their desired profitability in certain competitive market, more and more attention is paid to creating business processes and their performance. Optimization of these processes in many industries is achieved through mass production, but construction still does not allow building this way so easy. It should be noted that investors should pay attention to the execution of typical repeated projects, which could at least partially correspond to the concept of mass production.

\section{Definition of typical repeated projects}

Typical repeated building projects are described as building projects consisting of repetitive units. These repeatative units are similar solutions, works or locations with the same number of sequential actions. The typical repeated dwelling building project is an optimized project that focuses on most needs of users. The main advantage of the typical project is its cost, as it can be up to $50 \%$ less than a individual detacehed house project of the same size. Most of the Repeated dwelling building projects are simplified and do not need any special design solutions or solution are already rationally based. This is the best option for families who are unable to spend a lot of time and money on an individual house design an choose standard building with a standard plan, sometimes with solutions, repeated in other dwelling projects. Usually, it is estimated that such dwelling projects are built around 10-20 or even more times.

The construction time of typical repeated dwelling is not necessarily characterized by a certain starting and ending point, as is usually explained in a clearly defined period (Smith \& Tardif, 2009; Eastman, Teicholz, Sacks, \& Liston, 2011). In addition, it is a recurring activity that is more in line with the collection line than the usual project definition. The assembly line is a production line in which the material is constantly moving on a flat surface, passing the sequence of workstations. Work organization varies depending on the size of the product. The workforce carries out its activities in one house and moves to repeat its activities, as do the workers on the assembly line, except that the workers and equipment are moved here and production is organized in another house (Kwofie, Fugar, Adinyira, \& Ahadzie, 2014).

It would seem that repeated dwelling building projects are not unique if compared to traditional building projects, but are unique and distinguished by these features (Smith \& Tardif, 2009; Eastman et al., 2011; Adinyira, Ahadzie, \& Kwofie, 2013):

- Possibility to develop a repeat project in different locations;

- Clear investment and payback;

- Multiple/repeated standardized project units;

- Recurring infrastructure;

- Repeated project implementation tasks for clients, designers and builders;

- Use of typical items;

- Clear duration of construction;

- Clear need for materials, mechanisms and human resources; 
- Continuous improvement of the project, the project can be improved by taking into account possible mistakes in previously implemented projects;

- A cheaper project.

Although the development of repeated dwelling building projects has many advantages, the construction industry must use new building automation solutions to change the traditional production method and process management tools to increase project efficiency and performance.

\section{Application of Building Information Modelling}

BIM as an information management process, it ensures the development and management of various building data from all project disciplines and during whole project life cycle. The BIM process begins at an early stage of a feasibility study, extends to during the design stage, continue in the construction stages, transfer to the operation stage and ulimatly ends at the demolition stage (Smith \& Tardif, 2009; Eastman et al., 2011). Only consisten information management during all these stages ensure most-effective project implementation. Although the creation of BIM led to a breakthrough in technology and collaboration between the project team in the field of architecture, design, and construction (AEC), it was mostly implemented in commercial or large-scale construction projects, less for small projects and especially rarely for residential buildings (Giel \& Issa, 2011; Gronum, Verreynne, \& Kastelle, 2012).

The main reasons why BIM is rarely used (McGraw Hill 2014; Poirier, Staub-French, \& Forgues, 2015; Pavlovskis, Antucheviciene, \& Migilinskas, 2016):

- Lack of information about BIM or negative the opinion that BIM is only an hi-tec software for 3D modelling, ignoring new interdisciplinary collaborative processes between project participants during the whole project life cycle;

- High level of initial investment in new software, training and/or recruitment of new professionals to implement BIM;

- Builders' perception that residential projects are simple compared to commercial projects, and that BIM significantly improves project results (such as time, cost, and quality) only if used in complex projects;

- The severe crisis in the residential market over the past decade, influence a business owner opinion that investing money in innovative methods and technologies poses greater risks than benefits.

According to surveys $15 \%$ of residential builders are highly versed in BIM, while others $30 \%$ would like to use it in the future. BIM attracts the attention of residential builders as this methodology achieves better results, including time, cost, quality, and sustainability (Poirier et al., 2015). But it is not clear if the project's effectiveness realy grant benefits to business. A project is a temporary work with specific goals (such as building a house for a client) for which resources are assigned (for example, employees, software, and construction equipment), and business is a broader concept that covers the whole process and creates value or benefits (such as creating a marketing project, acquiring software, hiring, accounting, training, etc.) (Al-Debei \& Avison, 2010). Creating a residential construction business that supports BIM in residential projects will require a high initial investment in new software, training, and the recruitment of BIM experts. Therefore, while BIM promises more benefits for residential projects, it will take a long time for small house development companies to cover BIM deployment costs and start making profits.

\section{BIM benefits, opportunities, chalangies, disatvantageis and limitations}

The researchers in their literature analysis mostly highlights BIM benefits and opportunities in the construction industry but challenges, disatvantageis and limitations of BIM use aolso need to be anlysed (Azhar, 2011; Eastman et al., 2011; Migilinskas, Pavlovskis, Urba, \& Zigmund, 2017).

Benefits and Opportunities of BIM technologies (Jongeling, Kim, Fischer, Mourgues, \& Olofsson, 2008; Jalaei \& Jrade, 2015):

- Interdisciplinary cooperation for all project participants in one place;

- Parametric modelling and full element information;

- Change management and efficient control of conflicts;

- Specificity and automation in enchance design deliverables;

- Static and dynamic analysis of BIM model in any environment (construction, energy and sustainability analysis) before construction;

- Automation of construction processes and precise quantities for management;

$-5 \mathrm{D}$ modelling ensure overall control of 3D geometry, time and cost during whole project life cycle;

- Virtual construction of project can be tested to detect problems and assess the suitability;

- Virtual and Augmented Reality to make better visualisation and increase sales;

- Asset/facility management with BIM information to reduce operating costs and better planinig. 2011):

Challenges encountered during implementation of BIM technologies (Smith \& Tardif, 2009; Eastman et al.,

- Challanging interaction of disciplines and participants occur due use of different software and data transfer; 
- The size of BIM model depends on the level of detail and can have thousands of elements slowing down data processing and productivity of design;

- Time consuming preparation of BIM library may project may increas the efficiency of future projects comparing with standard library use;

- Client can quickly changes and ask for alternatives but in the detail design process demand more time to prepare deliverables.

Disadvantages and Limitations of BIM use (S. Liu, Xie, Tivendal, \& C. Liu, 2015; Migilinskas et al., 2017):

- Project participants are working with specific tools and often data ex-change is limited due to software incompatibility;

- Lack of clarity on data management, intellectual property and responsibility of participants with project content;

- The first use of BIM technologies is often the result of errors, due to lack of experience and leads to timeconsuming bug fixes;

- Lack of standards or the development of a national strategy for BIM implementation;

- Lack of competence of project participants using BIM technologies;

- Fear of failure and high initial investment costs;

- Time for training how to use the software;

- Too consoervative approach to new management technologies.

In Lithuania BIM technologies are being used by architects, structural and other engineers, contractors, manufacturers and building administrators who need to work together to simplify workflows and ensure that all design, construction and maintenance are effective but many participants and especially the client still think that BIM is too expensive for the Lithuanian construction industry (Pavlovskis et al., 2016; Migilinskas et al., 2017). The object of this research is to investigate the possibilities of application of BIM technologies in actually implemented typical and repetitive dwelling building projects. The analyzed projects of in total 10 houses have been developed in Vilnius district during the period between 2017 and 2019 years. The result of this research can be used for future analysis of possible BIM implementation issues in dwelling building projects.

\section{Methodology of the research}

The alternative analysis method has been chosen in this analysis. Three alternatives of implementation costs of typical dweling building project (see Figure 1) were analysed: planed in traditional way; using BIM methodology and analysing actual expenses. The traditional way is used to calculate the planed investment costs required for the project, the cost of project design, calculation of construction quantities from the design and preparation of the estimates. Using the BIM methodology and the design for architectural and structural parts have been made with BIM model, the investment cost for the BIM model use have been calculated, construction quantities have been generated from the BIM model and the estimates for construction work were prepared. When analyzing actual expenses, the date from company $\mathrm{X}$ have been used to identify the cost of this building project, the actual quantities of construction works and the actual costs for design and construction.

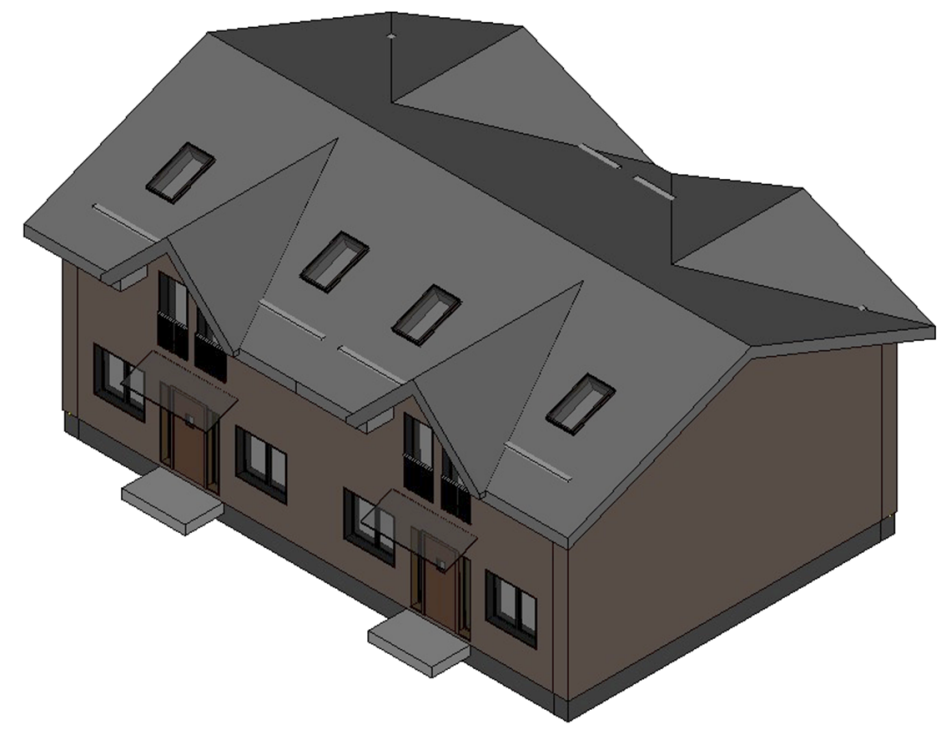

Figure 1. The BIM model of the research object 
The object selected for this research is a typical repeatative dwelling building project (set of semi-detached duplex houses) in Vilnius district implemented ten times in two site areas. The object is a two-story, small-scale and simple structure building matching the real eastate segment. This aim of this research is to analyse and to prove that the investment in BIM use for smaller multiple projects pays back if these projects are carried out by repeating the same project in same site area or even replacing the site. In order to prove to the client and to the final consumer that the execution of projects with BIM can bring benefits, data on possible ways to reduce costs must be collected and analysed as it shown in Table 1 and Figure 2.

Table 1. The evaluation of implementation costs in typical dweling building project

\begin{tabular}{|c|c|c|c|}
\hline Numer of buildings & Tradition way & BIM methotology & Actual expenses \\
\hline 1 & $10729 €$ & $13755 €$ & $10217 €$ \\
\hline 2 & $18499 €$ & $18635 €$ & $17991 €$ \\
\hline 3 & $24715 €$ & $22539 €$ & $24211 €$ \\
\hline 4 & $29688 €$ & $25662 €$ & $29186 €$ \\
\hline 5 & $33598 €$ & $28161 €$ & $33098 €$ \\
\hline 6 & $36675 €$ & $30159 €$ & $36177 €$ \\
\hline 7 & $39753 €$ & $32058 €$ & $39057 €$ \\
\hline 8 & $42830 €$ & $33856 €$ & $41736 €$ \\
\hline 9 & $45908 €$ & $35555 €$ & $44215 €$ \\
\hline 10 & $48985 €$ & $37153 €$ & $46495 €$ \\
\hline
\end{tabular}

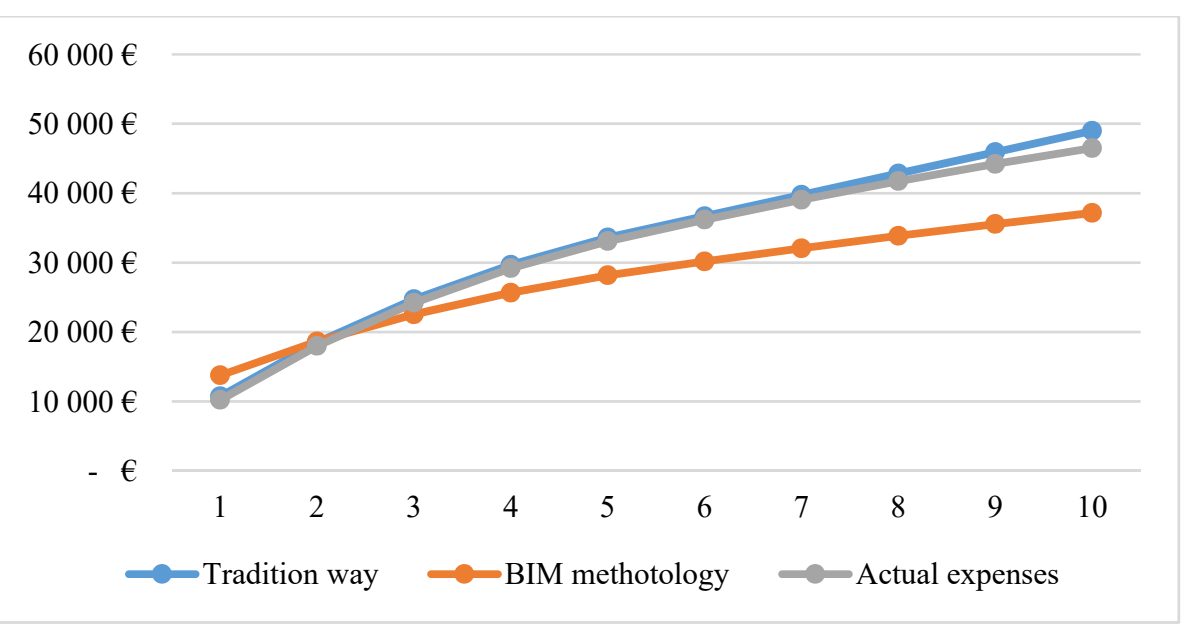

Figure 2. Digram of the implementation costs in typical dweling building project

The comaprisson of the implementation costs in typical dweling building project shows higher cost of the BIM investment for only one dwelling building and close making two of them but during implementation of third building project the pay back become positive with incresing trend at the end. Finishing of ten building based on the same typical dwelling building project grans less costs comparring both with implementation in traditional way and actual expenses. The difference is about 10000 euro and it corresponds to initial investment costs in beginning of project, for client it can be good pay back or economically effective starto of new project not taking in account other benefits of BIM methodology use. The BIM methodology is useful for repeated typical dwelling buildings projects, as it avoids (easier to see) errors in design, reduces project changes and errors, can be used to get more accurate estimates, runs more efficiently and faster, reduces construction time and costs.

\section{Results and conclusions}

During this research it was analysed the implementation of BIM technologies in repeated typical dwelling building projects and the following results were agregated:

1. The literature review has shown that BIM is rarely applied in small-scale objects due to the high initial investment.

2. After calculation of the investment costs of three project implementation options (traditional way, using BIM methodology and according to actual expenses) for the object of research, it was identified that the investment 
costs needed for the BIM methodology compared to the actual project expenses are 3.06 times higher. Mainly due to significantly more expensive software and hardware, software training and higher design costs.

3. In the research object implementation costs, it was found that the application of the BIM methodology (once per building attempt) is $41 \%$ higher than the savings and dwelling project without BIM duplication benefit has a negative investment return.

4. The assessment shows what two and fewer use of the BIM model have been found to have a negative project investment return (two times the return on investment $(-6 \%)$, and three (payback $+5 \%$ ) and for multiple BIM model use return on investment is increasing.

5. It is proposed that small businesses carry out repetitive projects with BIM, as the execution of repeated typical dwelling projects reduces the investment needed to implement BIM methodology in company and brings more benefits for efficient development of BIM in the future.

Final conclusion Building Information Modelling (BIM) can be treated as tool to increase project efficiency and performance but repeated use of BIM in building projects can bring even more benefits. Using of the BIM methodology in a project throughout its life cycle simplify the project's development process, make it easier to manage and can save both time and money for the end user.

\section{References}

Adinyira, E., Ahadzie, D. K., \& Kwofie, T. E. (2013). Determining the unique features of mass housing projects (MHPs). In Proceedings of the $5^{\text {th }}$ West Africa Built Environment Research (WABER) Conference. Accra, Ghana. Retrieved from https://www.researchgate.net/publication/236902886_DETERMINING_THE_UNIQUE_FEATURES_OF_MASS_HOUSING PROJECTS MHPs

Al-Debei, M. M., \& Avison, D. (2010). Developing a unified framework of the business model concept. European Journal of Information Systems, 19(3), 359-376. https://doi.org/10.1057/ejis.2010.21

Azhar, S. (2011). Building Information Modeling (BIM): trends, benefits, risks, and challenges for the AEC Industry. Leadership and Management in Engineering, 11(3), 241-252. https://doi.org/10.1061/(ASCE)LM.1943-5630.0000127

Eastman, C., Teicholz, P., Sacks, R., \& Liston, K. (2011). BIM handbook. A guide to building information modeling for owners, managers, designers, engineers, and contractors ( $2^{\text {nd }}$ ed.). New Jersey, USA: John Wiley \& Sons, Inc.

Eurostat. (2017). Urban Europe - statistics on cities, towns and suburbs - executive summary. Retrieved from https://ec.europa.eu/eurostat/statistics-explained/index.php?title=Housing_statistics\#Type_of_dwelling

Eurostat. (2018). Construction producer price and construction cost indices overview. Retrieved from http://ec.europa.eu/eurostat/statisticsexplained/index.php/Construction_producer_price_and_construction_cost_indices_overview

Giel, B. K., \& Issa, R. R. A. (2011). Return on investment analysis of using building information modeling in construction. Journal of Computing in Civil Engineering, 27(5). https://doi.org/10.1061/(ASCE)CP.1943-5487.0000164

Gronum, S., Verreynne, M. L., \& Kastelle, T. (2012). The role of networks in small and medium-sized enterprise innovation and firm performance. Journal of Small Business Management, 50(2), 257-282. https://doi.org/10.1111/j.1540-627X.2012.00353.x

Jalaei, F., \& Jrade, A. (2015). Integrating building information modeling (BIM) and LEED system at the conceptual design stage of sustainable buildings. Sustainable Cities and Society, 18, 95-107. https://doi.org/10.1016/j.scs.2015.06.007

Jongeling, R., Kim, J., Fischer, M., Mourgues, C., \& Olofsson, T. (2008). Quantitative analysis of workflow, temporary structure usage, and productivity using 4D models. Automation in Construction, 17(6), 780-791. https://doi.org/10.1016/j.autcon.2008.02.006

Kwofie, T. E., Fugar, F., Adinyira, E., \& Ahadzie, D. K. (2014). Identification and classification of the unique features of mass housing projects. Journal of Construction Engineering, Article ID 927652, 11. https://doi.org/10.1155/2014/927652

Liu, S., Xie, B., Tivendal, L., \& Liu, C. (2015). Critical barriers to BIM implementation in the AEC industry. International Journal of Marketing Studies, 7(6), 162. https://doi.org/10.5539/ijms.v7n6p162

Migilinskas, D., Pavlovskis, M., Urba, I., \& Zigmund, V. (2017). Analysis of problems, consequences and solutions for BIM application in reconstruction projects. Journal of Civil Engineering and Management, 23(8), 1082-1090. https://doi.org/10.3846/13923730.2017.1374304

Pavlovskis, M., Antucheviciene, J., \& Migilinskas, D. (2016). Application of MCDM and BIM for evaluation of asset redevelopment solutions. Studies in Informatics and Control, 25(3), 293-302. https://doi.org/10.24846/v25i3y201603

Poirier, E. A., Staub-French, S., \& Forgues, D. (2015). Measuring the impact of BIM on labor productivity in a small specialty contracting enterprise through action-research. Automation in Construction, 58, 74-84. https://doi.org/10.1016/j.autcon.2015.07.002

Smith, D. K., \& Tardif, M. (2009). Building information modeling: a strategic implementation guide for architects, engineers, constructors, and real estate asset managers. John Wiley \& Sons. https://doi.org/10.1002/9780470432846 